\title{
THE EFFECT OF TOPICAL CYCLOSPORIN ON CONJUNCTIVA-ASSOCIATED LYMPHOID TISSUE (CALT)
}

\author{
H. S. DUA ${ }^{1}$, V. K. JINDAL ${ }^{2}$, J. A. P. GOMES ${ }^{2,3}$, W. A. AMOAKU ${ }^{1}$, L. A. DONOSO ${ }^{2}$, \\ P. R. LAIBSON ${ }^{2}$ and K. MAHLBERG ${ }^{4}$ \\ Nottingham; Philadelphia, Pennsylvania; Sao Paolo, Brazil; Tampere, Finland
}

\begin{abstract}
SUMMARY
Topical cyclosporin $A$ is increasingly being used in the treatment of ocular surface immune-mediated disorders. The availability of the drug in oil-based vehicles or collagen shields has restricted its use because of ocular irritation or blurring of vision. Although topical cyclosporin is being used more frequently, its effect on the immunocompetent cells of the conjunctiva is not known. Our aim was to study the effect of cyclosporin instillation on the immunocomponent cells of conjunctiva-associated lymphoid tissue (CALT) of Lewis rat, using a novel method of topical drug delivery. A suspension of collagen bits impregnated with cyclosporin $A$ was instilled into eyes of Lewis rats for 4 days (group 1) or 8 days (group 2). Control rats (group 3) received the suspension without cyclosporin. Frozen sections of eyelids and conjunctiva were immunostained with the following monoclonal antibody markers: W3/13 (CD3), W3/25 (CD4, macrophages), OX-8 (CD8), MARD-3 (B cells), ED1, ED2 (macro/monocytes), OX-6 (class II MHC, Ia) and OX-39 (CD25, IL2 receptor). Intraepithelial (IE) and substantia propria cells for each subset were counted and expressed as numbers per section. By day 8, intraepithelial and substantia propria cells for all the above markers, except $B$ cells, showed a significant reduction in numbers. The $p$ values were $<0.02$ for $\mathrm{W3} / 13$ (CD3), W3/25 (CD4), OX-8 (CD8), OX-39 (CD25) (IE only), ED1, ED2 and OX-6 positive cells. Goblet cells of control animals showed strong positive reaction with OX-39 (CD25) antibody. This was completely abolished following 8 days of topical cyclosporin. This study demonstrated that topical cyclosporin $\mathbf{A}$ induces a
\end{abstract}

From: ${ }^{1}$ Department of Ophthalmology, Nottingham University, Nottingham, UK; ${ }^{2}$ Wills Eye Hospital, Philadelphia, Pennsylvania, USA; ${ }^{3}$ Santa Casa Medical School, Sao Paolo, Brazil; Leiras Eye Research, Tampere, Finland.

Correspondence to: Professor H. S. Dua, Department of Ophthalmology, B Floor, South Block, University Hospital, Queen's Medical Centre, Nottingham NG7 2UH, UK. marked reduction in numbers of all subtypes of immunocompetent cells in the conjunctival epithelium and substantia propria.

Cyclosporin A, a cyclic endecapeptide produced by the fungus species Tolypocladium inflatum Gams, is a potent immunomodulator. ${ }^{1}$ Although the precise mechanism of action is not understood, cyclosporin exerts a selective immunosuppressive effect by blocking an early stage in the activation of cytotoxic $\mathrm{T}$ lymphocytes in response to antigen. It may act through a variety of mechanisms including inhibition of the production of interleukin-2 and other cytokines, inhibition of $\mathrm{T}$ cell proliferation and clonal expansion, prevention of the activation of cytotoxic $\mathrm{T}$ lymphocytes and inhibition of certain T-cell-dependent B lymphocyte activity. ${ }^{1-4}$

Cyclosporin A has been used systemically, as an immunosuppressant, in the treatment of ocular inflammatory conditions such as Behçet's disease, ${ }^{5}$ Vogt Koyanagi Harada syndrome, sympathetic ophthalmitis, birdshot retinochoroidopathy, sarcoidosis and pars planitis. ${ }^{6}$ Significant nephrotoxicity, ${ }^{7,8}$ hypertension and hepatotoxicity ${ }^{1}$ have been associated with its use. Topical cyclosporin has been studied in the treatment of corneal graft rejections, ${ }^{9-13}$ peripheral corneal melting syndrome, outer eye inflammations, vernal conjunctivitis ${ }^{14}$ necrotising scleritis ${ }^{15}$ ligneous conjunctivitis, ${ }^{16}$ keratoconjunctivitis sicca ${ }^{3,17}$ and ulcerative keratitis, ${ }^{18}$ and in experimental herpetic stromal keratitis ${ }^{19}$ and experimental autoimmune uveitis. ${ }^{6,20,21}$ The effect of topical cyclosporin on the immune cells of normal conjunctiva of humans or experimental animals is not known.

Many vehicles for delivery of cyclosporin, such as vegetable oils, ${ }^{9,10,13}$ petrolatum-based ointment, ${ }^{22}$ Cremophor ${ }^{11}$ and alpha-cyclodextrin ${ }^{21}$ have been used but all these resulted in relatively low concentrations of drug to the cornea and anterior 
chamber. ${ }^{23}$ The use of collagen shields ${ }^{23}$ reduced the possibility of adverse systemic effects while achieving higher drug concentration in peripheral target tissues. The use of collagen shields is, however, associated with blurring of vision and consequent poor patient compliance. To overcome the poor compliance of the patient and the blurring effect of collagen corneal shields, we used collagen bits as vehicle for delivery of cyclosporin $\mathrm{A}$.

The Lewis rat model has been used extensively to study immune-mediated diseases, notably experimental autoimmune uveitis (EAU) $)^{20,24-26}$ and corneal graft rejections. ${ }^{12,27,28}$ It has recently been demonstrated that the conjunctiva is an integral part of the mucosal immune system and that the rat model can be used effectively to study immune responses in conjunctiva-associated lymphoid tissue. ${ }^{29-34}$

The present study was undertaken to assess the effects of topically administered cyclosporin A on the immunocomponent cells of the conjunctiva of Lewis rats and to evaluate the efficacy of a novel method of topical cyclosporin A administration, i.e. collagen bits impregnated with cyclosporin and suspended in artificial tears (Leiras Eye Research, Tampere, Finland).

\section{MATERIALS AND METHODS}

Collagen bits ( $0.5 \mathrm{~mm}$ square) impregnated with cyclosporin A drops were suspended in artificial tears (Tears plus: polyvinyl alcohol $1.4 \%$, providone $0.6 \%$ ) to give a final concentration of $0.5 \mathrm{mg} / \mathrm{ml}$. For controls, plain collagen bits were suspended in Tears plus.

Ten Lewis rats (6-8 weeks old) were divided into three groups. Cyclosporin A/collagen/artificial tears suspension was instilled $(10 \mu \mathrm{l})$ in each eye of 2 rats (group 1) twice daily for 4 days and in 4 rats (group 2 ) for 8 days. A further 4 rats (group 3) received plain collagen/artificial tears for 8 days and served as controls (Table I).

At the respective end points (days 4 and 8) all animals in each group were killed and the orbital contents, comprising of eye lids, conjunctiva and eyeball, exenterated en bloc. The tissues were immersed in a cryomatrix of Tissue-Tek OCT compound (Miles, Kankakee) and snap-frozen in liquid nitrogen. Frozen blocks were wrapped with Parafilm (American National Can) and stored at $-20{ }^{\circ} \mathrm{C}$ until sectioning. Five micrometre, longitudinal sections to

Table I. Eye drops instilled in the different groups of rats

\begin{tabular}{cccc}
\hline Group & No. of rats & Drops instilled & $\begin{array}{c}\text { Duration } \\
\text { (days) }\end{array}$ \\
\hline 1 & 2 & CSA/collagen/tears & 4 \\
2 & 4 & CSA/collagen/tears & 8 \\
3 & 4 & Collagen/tears & 8 \\
\hline
\end{tabular}

CSA, cyclosporin A. include palpebral, forniceal and bulbar conjunctiva of both upper and lower lids were obtained using the Reichert-Jung Cryocut 1800 system (Leica, Germany). Sections were placed on precleaned slides, Superfrost plus (Fischer Scientific, Pittsburgh), air-dried overnight and stained the next day or wrapped in foil and stored at $-20{ }^{\circ} \mathrm{C}$ before staining.

Animals were housed and treated in compliance with the Guidelines for Care and Use of Laboratory Animals (DHEW Publications, NIH 80-23).

\section{Immunohistochemistry}

The sensitive alkaline phosphatase/anti-alkaline phosphatase (APAAP) technique was used for immunostaining of tissues. Details of the method are described elsewhere. ${ }^{33}$ Cryostat sections (10 per specimen) were fixed in acetone for 10 minutes, airdried for 5 minutes and primary antibodies applied in appropriate dilutions (Table II) for 1 hour. Rabbit anti-mouse polyclonal antibody (1:40 for 30 minutes; DAKO, Carpinteria) was used as secondary linking antibody and monoclonal APAAP mouse (1:40 for 30 minutes; DAKO) was used as the tertiary antibody. Both secondary and tertiary antibodies were absorbed with pooled, heat-inactivated, normal rat serum $(20 \%)$ for 30 minutes before use. TRISbuffered normal saline ( $\mathrm{pH}$ 7.6) was used as wash buffer between steps and as negative control. Antibody dilutions were made in the wash buffer. After incubation with tertiary antibody, slides were washed and developed for 15-20 minutes in Fast Red substrate solution. All slides were counterstained with Meyer's haematoxylin and mounted in GelMount (Biomeda, Foster City) aqueous mounting medium. Positive, red-stained cells were counted through the entire section including palpebral, forniceal and bulbar conjunctiva of both upper and lower lids (separately for epithelium and substantia propria) at a magnification of $\times 400$ by two independent, masked observers and averaged. Cell counts were expressed as numbers per section (including palpebral, forniceal and bulbar conjunctiva of both lids). Variation in counts between the two observers was between $1 \%$ and $3 \%$.

Table II. Panel of monoclonal antibody markers used to identify immune cell subsets

\begin{tabular}{lc}
\hline Antigen specificity & Clone $^{\mathrm{a}}$ \\
\hline $\begin{array}{l}\text { T lymphocytes (CD3), plasma cells, polymorphs, } \\
\text { stem cells }\end{array}$ & W3/13 \\
T suppressor/cytotoxic cells (CD8) & MRC OX-8 \\
T helper cells (CD4) and macrophages & W3/25 \\
Activated T cells (IL-2R, CD25) & MRC OX-39 \\
IgD heavy chain (B lymphocytes) & MARD-3 \\
Ia antigen (B cells, dendritic cells, some & \\
macrophages) & MRC OX-6 \\
Macrophages, monocytes and dendritic cells & ED-1 \\
Macrophages & ED-2 \\
\hline
\end{tabular}

${ }^{\mathrm{a} S e r o t e c ~ L t d, ~ O x f o r d, ~ U K . ~}$ 


\section{Statistical Analysis}

A global significance was first achieved for all the three groups (two experimental groups, day 4 and day 8, and one control group) using the KruskalWallis non-parametric analysis of variance (ANOVA). If the global $p$ value was significant, Dunn's multiple comparison procedure (non-parametric) was performed on all pairwise comparisons, at an overall significance level of $(\alpha=) 0.05$.

In the second analysis pairwise comparisons between the controls and each treatment group were also performed with the Mann-Whitney $U$ test (non-parametric) with no adjustment for multiple outcomes. The $p$ values for this were all twotailed.

\section{RESULTS}

Externally, all 20 eyes were absolutely normal without any signs of inflammation, congestion or discharge.

On immunohistology of the control group (group 3) (Table III), we observed a large number of immune cells in the rat conjunctiva. There was a marked preponderance of cells belonging to the macrophage, monocyte, dendritic cell immunophenotype as stained with monoclonal antibodies (Mab) ED1 and ED2. In general, the greater proportion of all cell types were located in the substantia propria as compared with the epithelium - except for cells staining positive for the interleukin-2 (IL2) receptor (CD25), which were present in a greater proportion in the epithelium. CD8 positive (OX-8) cells were almost equally distributed between the two locations.

Analysis of the comparison of individual cell types in conjunctiva of the control group with that of conjunctiva of the two groups treated with cyclosporin A (Table III) revealed, in general, a decrease in the population of all cell types. In the control group over $80 \%$ of $\mathrm{T}$ lymphocytes, bearing the pan $\mathrm{T}$ cell marker (W3/13, CD3), were situated in the substantia propria. In cyclosporin A treated groups the conjunctiva showed a decrease in T lymphocytes, which was most marked in group 2 (8 days of cyclosporin A), to $20 \%$ of the control group intraepithelially and $12 \%$ of the control in the substantia propria. Similarly in controls, about $90 \%$ of the cells staining with Mab W3/25 (CD4, T helpers and macrophages) were found in the substantia propria, with the intraepithelial population accounting for approximately $9 \%$. The cyclosporin A treated groups again showed a reduced population of these cells to under $22 \%$ of controls intraepithelially and $55 \%$ of controls in the substantia propria.

The suppressor/cytotoxic T lymphocytes (OX-8, CD8) were more evenly distributed between intraepithelial and substantia propria locations. They were reduced to just over $30 \%$ of the control group intraepithelially and to $50 \%$ in the substantia propria, by day 8 of cyclosporin A administration.

Cells staining positive for interleukin-2 (IL2) receptor (MRC OX-39, CD25) were observed more in the intraepithelial location than in the substantia propria. A significant effect of cyclosporin A was noticed in the cell population of group 2, with a reduction of positive cells to $6 \%$ intraepithelially and to $21 \%$ in the substantia propria. Interestingly, the contents of the goblet cells also stained positive with Mab OX-39 (IL2 receptor, CD25) in all conjunctival

Table III. Number of immune cells $\mathrm{s}^{\mathrm{a}}$ in controls and cyclosporin A (CSA) treated animals

\begin{tabular}{|c|c|c|c|c|c|c|}
\hline \multirow[b]{3}{*}{ Antibody marker used } & \multirow[b]{3}{*}{ Site } & \multicolumn{3}{|c|}{ No. of immune cells } & \multirow{2}{*}{\multicolumn{2}{|c|}{ Significance $^{\mathrm{b}}$ CSA vs controls }} \\
\hline & & & CS & ted & & \\
\hline & & Controls & Day 4 & Day 8 & Day 4 & Day 8 \\
\hline $\begin{array}{l}\text { W3-25 } \\
\text { (CD4, helper) }\end{array}$ & $\begin{array}{l}\text { IE } \\
\text { SP }\end{array}$ & $\begin{array}{r}18.25 \\
200.50\end{array}$ & $\begin{array}{r}12.50 \\
170.50\end{array}$ & $\begin{array}{r}4.00 \\
111.25\end{array}$ & $\begin{array}{l}0.13 \\
0.06\end{array}$ & $\begin{array}{l}0.01 \\
0.01\end{array}$ \\
\hline $\begin{array}{l}\text { W3-13 } \\
(\mathrm{CD} 3 \text {, pan T) }\end{array}$ & $\begin{array}{l}\text { IE } \\
\text { SP }\end{array}$ & $\begin{array}{r}5.75 \\
22.50\end{array}$ & $\begin{array}{r}8.50 \\
17.00\end{array}$ & $\begin{array}{l}1.25 \\
2.75\end{array}$ & $\begin{array}{l}0.06 \\
0.13\end{array}$ & $\begin{array}{l}0.01 \\
0.01\end{array}$ \\
\hline $\begin{array}{l}\text { OX-8 } \\
\text { (CD8, suppressor) }\end{array}$ & $\begin{array}{l}\text { IE } \\
\text { SP }\end{array}$ & $\begin{array}{l}5.25 \\
6.00\end{array}$ & $\begin{array}{r}5.00 \\
14.00\end{array}$ & $\begin{array}{l}1.75 \\
3.00\end{array}$ & $\begin{array}{l}0.60 \\
0.06\end{array}$ & $\begin{array}{l}0.05 \\
0.05\end{array}$ \\
\hline $\begin{array}{l}\text { OX-39 } \\
\text { (CD25, IL-2R) }\end{array}$ & $\begin{array}{l}\text { IE } \\
\text { SP }\end{array}$ & $\begin{array}{r}15.50 \\
4.75\end{array}$ & $\begin{array}{r}12.50 \\
1.00\end{array}$ & $\begin{array}{l}1.00 \\
1.00\end{array}$ & $\begin{array}{l}0.26 \\
0.26\end{array}$ & $\begin{array}{l}0.01 \\
0.17\end{array}$ \\
\hline $\begin{array}{l}\text { MARD-3 } \\
\text { (B-cells) }\end{array}$ & $\begin{array}{l}\text { IE } \\
\text { SP }\end{array}$ & $\begin{array}{l}1.25 \\
4.00\end{array}$ & $\begin{array}{l}4.00 \\
0.00\end{array}$ & $\begin{array}{l}0.25 \\
2.25\end{array}$ & $\begin{array}{l}0.13 \\
0.13\end{array}$ & $\begin{array}{l}0.10 \\
0.34\end{array}$ \\
\hline $\begin{array}{l}\text { OX-6 } \\
\text { (Ia antigen) }\end{array}$ & $\begin{array}{l}\text { IE } \\
\text { SP }\end{array}$ & $\begin{array}{l}25.75 \\
72.00\end{array}$ & $\begin{array}{l}27.50 \\
52.50\end{array}$ & $\begin{array}{l}14.75 \\
30.00\end{array}$ & $\begin{array}{l}0.60 \\
0.06\end{array}$ & $\begin{array}{l}0.02 \\
0.01\end{array}$ \\
\hline $\begin{array}{l}\text { ED-1 } \\
\text { (macro-, monophages) }\end{array}$ & $\begin{array}{l}\text { IE } \\
\text { SP }\end{array}$ & $\begin{array}{r}8.50 \\
106.75\end{array}$ & $\begin{array}{r}6.00 \\
84.00\end{array}$ & $\begin{array}{r}3.50 \\
69.50\end{array}$ & $\begin{array}{l}0.13 \\
0.06\end{array}$ & $\begin{array}{l}0.01 \\
0.01\end{array}$ \\
\hline $\begin{array}{l}\text { ED-2 } \\
\text { (macrophage) }\end{array}$ & $\begin{array}{l}\mathrm{IE} \\
\mathrm{SP}\end{array}$ & $\begin{array}{r}5.25 \\
243.00\end{array}$ & $\begin{array}{r}5.50 \\
189.50 \\
\end{array}$ & $\begin{array}{r}0.75 \\
163.50 \\
\end{array}$ & $\begin{array}{l}0.40 \\
0.06 \\
\end{array}$ & $\begin{array}{l}0.01 \\
0.01 \\
\end{array}$ \\
\hline
\end{tabular}

IE, intraepithelial; SP, substantia propria.

${ }^{a}$ Cell numbers are counts per section including palpebral, forniceal and bulbar conjunctiva of both lids.

bStatistical analysis is detailed in Materials and Methods. 


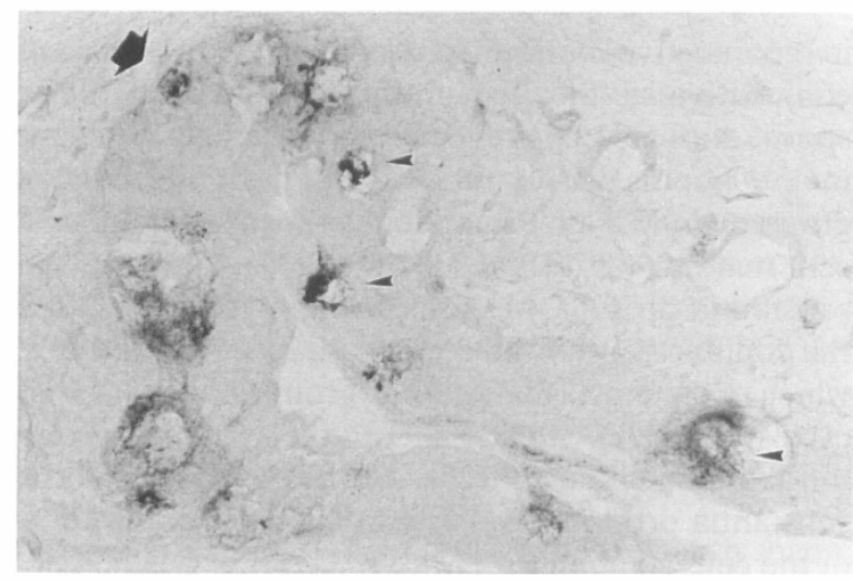

Fig. 1. Immunohistology of normal rat conjunctiva (group 3 , control) stained with $O X-39$ (CD25) anti-IL2 receptor antibody. The contents of goblet cells show strong positive staining (arrowheads). The large arrow indicates the superior conjunctival fornix. $(A P A A P, \times 400)$.

sections of controls (Fig. 1). Cyclosporin A treatment for 8 days completely abolished OX-39 (CD25) staining of goblet cells (Fig. 2).

In the controls, cells expressing the MHC class II, Ia antigen (MRC OX-6) were 3 times more numerous in the substantia propria than in the epithelium. After 8 days of cyclosporin A treatment (group 2), OX-6 positive cells had decreased to under $60 \%$ of controls in the epithelium and to just over $40 \%$ in the substantia propria.

Cells staining positively with Mab ED1 (macrophages, monocytes and dendritic cells) and ED2 (macrophages) were by far the largest population of the cells observed, and were found almost entirely $(92-97 \%)$ in the substantia propria. Compared with the controls, in cyclosporin A treated animals (group 2) ED1 positive cells had decreased to $40 \%$ and ED2 positive cells to $14 \%$ in the epithelium and to $65 \%$ (ED1) and 67\% (ED2) in the substantia propria.

B cells, as stained with the anti-IgD heavy chain antibody MARD-3, were the least prevalent of all cell types, with the majority $(76 \%)$ in the substantia propria. The B cell population was not significantly reduced by cyclosporin A treatment.

\section{DISCUSSION}

Topical cyclosporin A has been used beneficially in the treatment of several ocular surface diseases such as peripheral corneal melting syndrome, vernal conjunctivitis, ${ }^{14}$ necrotising scleritis, ${ }^{15}$ ligneous conjunctivitis, ${ }^{16}$ keratoconjunctivitis sicca ${ }^{3,17}$ and ulcerative keratitis. ${ }^{18}$ Its use, however, has been restricted by its insolubility in aqueous vehicles and the symptoms of irritation and blurred vision associated with oil-based vehicles and collagen shields. Collagen is non-irritant and hypoallergenic. Reidy et al. ${ }^{23}$ have shown that collagen shields are an effective means for delivery of cyclosporin A. The patient's vision,
Fig. 2. Immunohistology of rat conjunctiva (group 2) taken 8 days after topical cyclosporin A instillation, stained with OX-39 (CD25) anti-IL2 receptor antibody. The contents of goblet cells do not show positive staining. (APAAP, $\times 400)$.

however, remains blurred until dissolution of the collagen shield is complete. Results of our study indicate that collagen bits offer an effective alternative method for the topical administration of cyclosporin A. Although we have not used this preparation in humans, its effect on vision and symptoms of irritation is expected to be relatively less. The animals eyes did not show any signs of irritation, in the form of redness, watering or lid swelling, during the course of treatment. The efficacy of this method of drug delivery was supported by the observed immunosuppressant effect of cyclosporin A on the immunocompetent cells of the conjunctiva.

In this study, the rat conjunctiva of the control group presented a similar immunophenotypical distribution of lymphocytes and other immunocompetent cells to that seen in the human conjunctiva. ${ }^{33}$ The results of the control group are similar to our recent study reporting the normal profile of immunocompetent cells in rat CALT (submitted).

Cyclosporin A is believed to exert its immunosuppressive effect through a variety of mechanisms, including inhibition of the production of IL2 and other cytokines, inhibition of $T$ cell proliferation and clonal expansion, prevention of the activation of cytotoxic $\mathrm{T}$ lymphocytes and inhibition of certain $\mathrm{T}$ cell-dependent B lymphocyte activity. ${ }^{1-3}$ Inhibition of $\mathrm{T}$ lymphocyte activation is critical to the immunosuppressive effect. Cyclosporin A interferes with $\mathrm{T}$ lymphocyte ability to produce the lymphokine IL2 or respond to IL2 by preventing the formation of specific IL2 receptors. This lymphokine is thought to be the primary path by which $\mathrm{T}$ lymphocytes continue to recruit and activate new $\mathrm{T}$ cells. The expression of IL2 receptor (CD25) is critical for the $\mathrm{T}$ cell capacity to respond to this lymphokine. ${ }^{4}$ Immunohistochemistry of the conjunctiva of eyes treated with cyclosporin A for 4 and 8 days showed a 
gradual decrease in the populations of all immunocomponent cells. There was significant decrease in the total number of $\mathrm{T}$ lymphocytes, with the greatest decrease in the cells expressing IL2 receptors (OX$39, \mathrm{CD} 25$ intraepithelial) and cytotoxic/suppressor T lymphocytes (OX-8, CD8). A decrease in $\mathrm{W} 3 / 25$ (CD4) bearing cells suggests a decrease in T helpers, but it has to be kept in mind that this antibody also stains macrophages. A morphological distinction between lymphocytes and macrophages was not attempted.

A decrease in the number of macrophages, monocytes and cells expressing MHC classs II, Ia antigen was observed. Similar results were found in human conjunctiva in ligneous conjunctivitis after treatment with topical cyclosporin prepared in olive oil. ${ }^{16}$ It is interesting to note that although cyclosporin specifically targets the $\mathrm{T}$ helper/inducer subset of lymphocytes its 'knock-on' effect results in a generalised suppression of all cell types including mononuclear cells, with the exception perhaps of $\mathrm{B}$ lymphocytes.

Our study supports the notion that local immunosuppression can be achieved by the topical administration of cyclosporin $\mathrm{A}$ in rats, and also indicates that cyclosporin A can affect the population of immunocompetent cells in normal conjunctiva. The Lewis rat should prove to be a good model for immunological studies of the ocular surface.

Key words: Conjunctiva, Cyclosporin, Lymphoid tissue.

\section{REFERENCES}

1. Belin MW, Bouchard CS, Phillips TM. Update on topical cyclosporine A: background, immunology, and pharmacology. Cornea 1990;9:184-95.

2. Hess AD, Esa AH, Colombani PM. Mechanism of action of cyclosporine: effects on cells of the immune system and on subcellular events in T cell activation. Transplant Proc 1988;20(Suppl):29-40.

3. Laibovitz RA, Solch S, Andriano K, Connell MO, Silverman MH. Pilot trial of cyclosporine $1 \%$ ophthalmic ointment in the treatment of keratoconjunctivitis sicca. Cornea 1993;12:315-23.

4. Nussenblatt RB, Palestine AG. Cyclosporine: immunology, pharmacology and therapeutic use. Surv Ophthalmol 1986;31:159-69.

5. Casper-Velu LE, Decaux G, Libert J. Cyclosporine in Behçet disease resistant to conventional therapy. Ann Ophthalmol 1989;21:111-8.

6. Kaan G, Ozden O. Therapeutic uses of topical cyclosporine. Ann Ophthalmol 1993;25:182-6.

7. Palestine AG, Nussenblat RB, Chan CC. Side effects of systemic cyclosporine in non transplant patients. Am J Med 1984;77:652-6.

8. Palestine AG, Austin HA, Balow JE, Antonvych TT, Sabnis SG, Preuss HG, Nussenblatt RB. Renal histopathologic alterations in patients treated with cyclosporine for uveitis. N Engl J Med 1986;314: 1293-8.

9. Foets B, Missotten L, Vanderveeren P, Goossens W. Prolonged survival of allogenic corneal graft in rabbits treated with topically applied cyclosporine A, systemic absorption and local immunosuppression. $\mathrm{Br} \mathrm{J}$ Ophthalmol 1985;69:600-3.

10. Hunter PA, Garner A, Wilhelinus KR, Rice NS, Jones BR. Corneal graft rejection: a rabbit model and cyclosporine A. Br J Ophthalmol 1982;66:292-302.

11. Kana JS, Hoffman F, Buchen R, Krolik A, Wiederholt M. Rabbit corneal allograft survival following topical administration of cyclosporine A. Invest Ophthalmol Vis Sci 1982;22:686-90.

12. Milani JK, Pleyer U, Dukes A, Chou J, Lutz S, Ruckert D, Schmidt K, Mondino BJ. Prolongation of corneal allograft survival with liposome-encapsulated cyclosporine in the rat eye. Ophthalmology 1993;100:890-6.

13. Salisbury JD, Gebhardt BM. Suppression of corneal graft rejection by cyclosporine A. Arch Ophthalmol 1981;99:1640-3.

14. BenEzra D, Pe'er J, Brodsky M, Cohen E. Cyclosporine eye drops for the treatment of severe vernal keratoconjunctivitis. Am J Ophthalmol 1986;101: 278-82.

15. Hoffman F, Wiederholdt M. Local treatment of necrotizing scleritis with cyclosporine A. Cornea 1985;4:3-7.

16. Holland EJ, Chan CC, Kuwabara T, Palestine AG, Rowsey JJ, Nussenblatt RB. Immunohistologicfindings and results of treatment with cyclosporine in ligneous conjunctivitis. Am J Ophthalmol 1989;107:160-6.

17. Kaswan RL, Salisbury MA, Ward DA. Spontaneous canine keratoconjunctivitis sicca: a useful model for human keratoconjunctivitis sicca. Treatment with cyclosporine eye drops. Arch Ophthalmol 1989; 107:1210-6.

18. Liegner JT, Yee RW, Wild JH. Topical cyclosporine therapy for ulcerative keratitis associated with rheumatoid arthritis. Am J Ophthalmol 1990;109:610-2.

19. Boisjoly HM, Woog JJ, Pavan-Langston, Park NH. Prophylactic topical cyclosporine in experimental herpetic stromal keratitis. Arch Ophthalmol 1984; 102:1804-7.

20. Nussenblatt RB, Dinning WJ, Fujikawa LS, Chan CC, Palestine AG. Local cyclosporine therapy for experimental autoimmune uveitis in rats. Arch Ophthalmol 1985; 103:1559-62.

21. Sasmoto Y, Hirose S, Ohno S, Onoe K, Matsuda H. Topical application of cyclosporin ophthalmic solution containing alpha-cyclodextrin in experimental uveitis. Ophthalmologica 1991;203:118-25.

22. Mosteller MW, Gebhardt BM, Hamilton AM, Kaufman HE. Penetration of topical cyclosporine into the rabbit cornea, aqueous humour and serum. Arch Ophthalmol 1985;103:101-2.

23. Reidy JJ, Gebhardt BM, Kaufman HE. The collagen shield: a new vehicle for delivery of cyclosporine A to the eye. Cornea 1990;9:196-9.

24. Forrester JV, Liversidge J, Dua HS, Towler H, McMenamin PG. Comparison of clinical and experimental uveitis. Curr Eye Res 1990;9(Suppl):75-84.

25. Forrester JV, Liversidge J, Dua HS, Dick A, Harper F, McMenamin PG. Experimental autoimmune uveoretinitis: a model for immune intervention. Curr Eye Res 1992; 11(Suppl):33-40.

26. Dua HS, Donoso LA. Function in the immune system of antigenic peptides from S-antigen (Arrestin). Methods: A Companion to Methods Enzymol 1993; 5:242-51.

27. Herbort CP, Matsubara M, Nishi M, Mochizuki M. Penetrating keratoplasty in the rat: a model for immunosuppressive treatment of graft rejection. Jpn J Ophthalmol 1989;33:212-20. 
28. Nishi M, Herbort CP, Matsubara M, Morishita Y, Nishimura M, Nieda M, Mori S, Mochizuki M. Effects of the immunosuppressant FK 506 on a penetrating keratoplasty rejection model in the rat. Invest Ophthalmol Vis Sci 1993;34:2477-86.

29. Dua HS, Donoso LA, Laibson PR. Conjunctival instillation of retinal antigens induces tolerance. Does it invoke mucosal tolerance mediated via conjunctival associated lymphoid tissue (CALT)? Ocular Immunol Inflam 1994;2:29-36.

30. Dick AD, Cheng YF, Mckinnon A, Liversidge J, Forrester JV. Nasal administration of retinal antigen suppresses the inflammatory response in experimental allergic uveoretinitis: a preliminary report of intranasal induction of tolerance with retinal antigens. $\mathrm{Br} \mathrm{J}$ Ophthalmol 1993;77:171-5.

31. Nussenblatt RB, Caspi RR, Mahdi R, Chan CC,
Roberge F, Lider O, Weiner HL. Inhibition of Santigen induced experimental autoimmune uveoretinitis by oral induction of tolerance with S-antigen. J Immunol 1990;144:1689-95.

32. Vrabec TR, Gregerson DS, Dua HS, Donoso LA. Inhibition of experimental autoimmune uveitis by oral administration of S-antigen and synthetic peptides. Autoimmunity 1992;12:175-84.

33. Dua HS, Gomes JAP, Jindal VK, Appa SN, Schwarting R, Eagle RC, Donoso LA, Laibson PR. Mucosa specific lymphocytes in human conjunctiva, corneoscleral limbus and lacrimal gland. Curr Eye Res 1994; 13:87-93.

34. Dua HS, Gomes JAP, Donoso LA, Laibson PR. The ocular surface as part of the mucosal immune system: conjunctival mucosa-specific lymphocytes in ocular surface pathology. Eye 1995;9:261-7. 